\title{
ANALISIS PARAMETER GEMPABUMI DENGAN STRUKTUR GEOLOGI DI DAERAH ASPARAGA, GORONTALO
}

\author{
Ratna Sari Madusila $^{\mathrm{a}}$, Intan Noviantari Manyoe ${ }^{\mathrm{a}}$, Cindi Claudia Male \\ a Teknik Geologi, Universitas Negeri Gorontalo, Gorontalo 96554, Indonesia
}

\section{ARTICLE INFO}

\section{Article history:}

Received: 10 December 2020

Accepted: 8 January 2021

Published: 19 January 2021

\section{Keywords:}

Depth; Geological Structure; Lineament; Magnitude; Zoning

\section{Corresponding author:}

Intan Noviantari Manyoe

Teknik Geologi, Universitas Negeri

Gorontalo, Gorontalo, Indonesia

Email:intan.manyoe@ung.ac.id

\begin{abstract}
Gorontalo is an area located in the North Arm of Sulawesi which has a complex geological structure as a result of the submergence of the Sulawesi Sea and East Sangihe so that this area is considered an earthquake-prone area. The existence of the regional structure and the mapping of the earthquake point distribution is interesting to be studied more deeply because it affects seismic activity in the area. The purpose of this study is to analyze earthquakes in the Asparaga area based on their depth and magnitude and to relate them to the geological structures found in the study area. The earthquake data used were obtained from USGS. Satellite image data used is the SRTM satellite image. Earthquake data is mapped to produce depth maps, magnitude maps, and earthquake zoning maps. Lineament data were processed using a rosette diagram. Lineament can reflect the morphology observed on the earth's surface as a result of the activity of geological forces. The results showed that the Asparaga area had shallow earthquake depths and moderate to large magnitudes. The focus of the earthquake was right on the path traversed by the geological structure and its relatively northwest-southeast direction. The geological structure in the research location is the epicenter of the earthquake because it is crossed by regional geological structures.
\end{abstract}

Copyright (C) 2021 The Authors This open access article is distributed under a Creative Commons Attribution (CC-BY) 4.0 International license

\section{Pendahuluan}

Provinsi Gorontalo terletak di Indonesia bagian timur dan dibentuk oleh beberapa subduksi yaitu subduksi Laut Sulawesi yang berada di sebelah utara serta subduksi Sangihe Timur yang berada di sebelah tenggara (Simandjuntak, 1992). Gorontalo merupakan kawasan yang memiliki aktivitas tektonik yang sangat aktif. Hal ini disebabkan oleh adanya aktivitas seismik dan percepatan tanah di wilayah tersebut. Gorontalo memiliki struktur geologi berupa lipatan dan patahan. Beberapa sesar aktif yang terdapat di wilayah Gorontalo berupa sesar normal dan sesar geser (Apandi \& Bachri, 1997; Bachri et al., 1993). Kondisi tektonik yang sangat kompleks di Gorontalo menyebabkan wilayah Gorontalo rentan akan terjadinya bahaya gempabumi dan tsunami. Kegempaan tersebut dipengaruhi karena adanya subduksi dan sesar aktif. Pergerakan tanah menyebabkan terjadinya bahaya gempabumi, baik sumbernya gempabumi dangkal maupun gempabumi dalam.

Penelitian yang mengkaji mengenai struktur geologi aktif baik regional maupun lokal, menurut Soehaimi (2008) sebaiknya ditekankan pada hubungan antara kondisi geologi dan kegempaan suatu wilayah. Kondisi geologi tersebut berupa tektonik, struktur geologi, dan batuan sedangkan kegempaan wilayah meliputi episentrum, kedalaman, kekuatan, dan intensitas.

Beberapa penelitian terdahulu membahas mengenai aktivitas seismik yang terjadi di wilayah Gorontalo dan sekitarnya diantaranya (Massinai et al., 2019; Manyoe et al., 2019) serta kondisi tektonik dan keterdapatan struktur geologi (Hall \& Wilson, 2000; Milsom, 2001; Hinschberger et al., 2005; Molnar \& Dayem, 2010; Advokaat et al., 2017). Penelitian yang dilakukan oleh Manyoe et al., (2019), menganalisis tingkat kerusakan yang diakibatkan oleh gempabumi berdasarkan aktivitas 
seismik dan percepatan tanah di wilayah Gorontalo. Metode yang digunakan dalam penelitian terdahulu yaitu metode seismisitas berupa pembuatan peta seismisitas menggunakan perangkat lunak Quantum Geographical Information System (QGIS) dan metode Peak Ground Acceleration (PGA) yang menyediakan hubungan antara percepatan tanah $(\alpha)$, magnitudo $(\mathrm{M})$ dan jarak pusat gempa $(\Delta)$. Kelebihan dari metode tersebut dapat diketahui tingkat kerusakan akibat gempabumi dan percepatan tanah. Namun, penelitian ini dilakukan dalam skala luas serta tidak membuat peta zonasi kedalaman dan peta zonasi magnitudo sehingga perlu dilakukan penelitian kegempaan detail di tiap-tiap daerah di Gorontalo.

Salah satu daerah yang perlu diwaspadai dari bahaya gempabumi adalah daerah Asparaga. Asparaga berada di Kecamatan Asparaga, Kabupaten Gorontalo, Provinsi Gorontalo (Gambar 1). Gorontalo berhadapan langsung dengan subduksi Laut Sulawesi dan subduksi Sangihe Timur. Sesar normal dan sesar geser merupakan sesar utama yang terdapat di wilayah Gorontalo. Hal tersebut menyebabkan daerah Asparaga merupakan salah satu daerah di Gorontalo yang rawan gempabumi. Terdapat titik-titik gempa di daerah Asparaga yang diperkirakan dapat menyebabkan kerusakan hingga ke permukaan dan adanya beberapa struktur geologi. Akan tetapi pada daerah ini belum dilakukan penelitian untuk menganalisis kegempaan dan kaitannya dengan struktur geologi.

Berdasarkan peta geologi regional, litologi yang terdapat di daerah penelitian yaitu Endapan Danau (Qpl), Diorit Boliohuto (Tmbo), Formasi Dolokapa (Tmd), dan Breksi Wobudu (Tpwv). Endapan Danau tersusun atas batulempung, batupasir, dan kerikil sedangkan Diorit Boliohuto (Tmbo) tersusun atas diorit, granodiorit. Formasi Dolokapa (Tmd) tersusun atas batupasir wacke, batulanau, batulumpur, konglomerat, tuf, tuf lapili, aglomerat, breksi gunungapi, dan lava andesitik-basaltik sedangkan Breksi Wobudu (Tpwv) tersusun atas breksi gunungapi, aglomerat, tuf, tuf lapilli, lava andesitan dan basalan.

Penelitian ini dilengkapi dengan peta zonasi kedalaman dan peta zonasi magnitudo yang akan dikaitkan dengan titik gempa yang berada di jalur struktur geologi. Adapun tujuan dari penelitian ini yaitu menganalisis gempabumi daerah Asparaga berdasarkan kedalaman dan magnitudo gempabumi serta menghubungkannya dengan struktur geologi yang bekerja pada daerah penelitian.

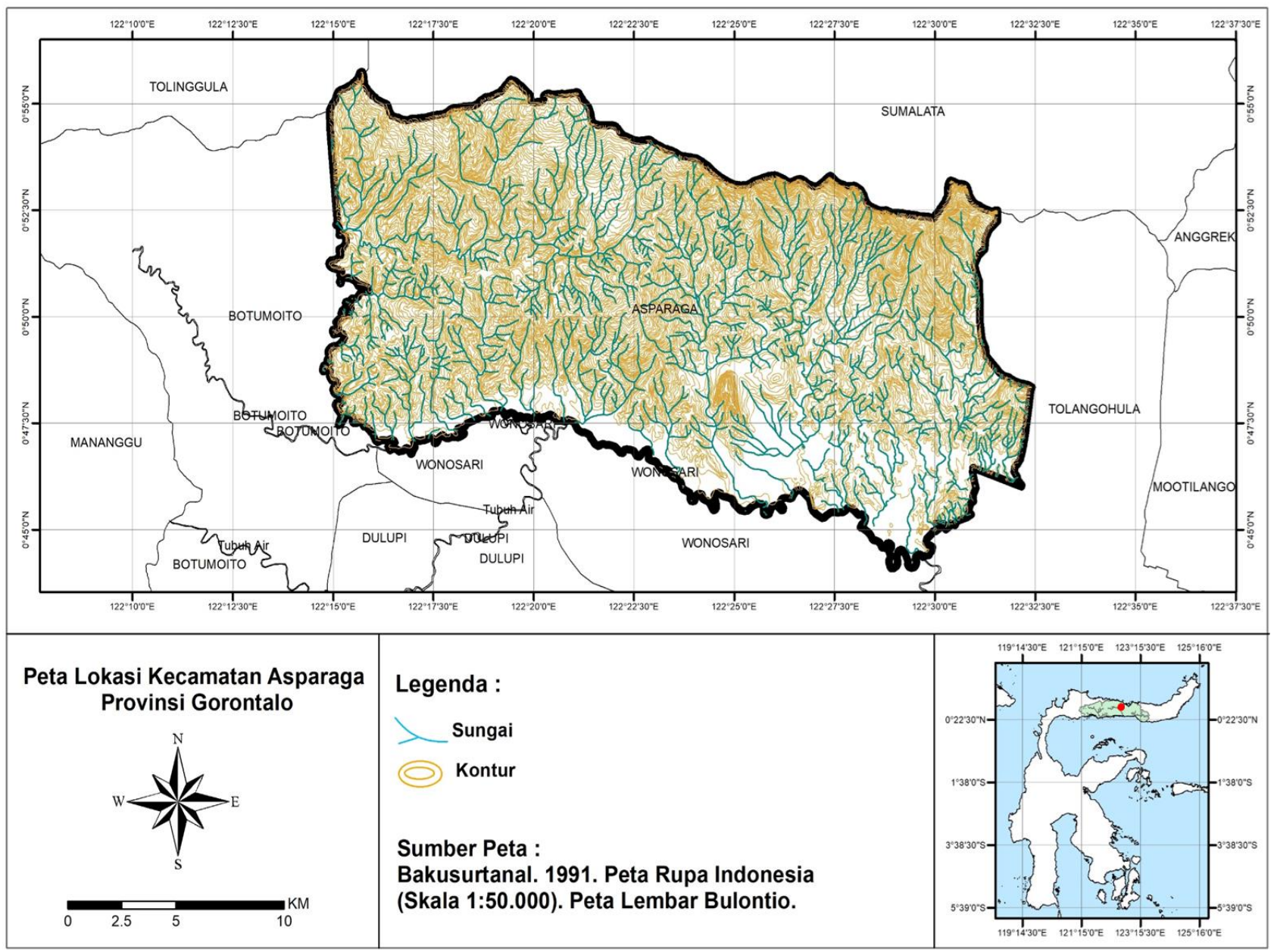

Gambar 1. Peta lokasi penelitian 


\section{Metode}

\subsection{Parameter Gempa}

Data yang digunakan dalam penelitian ini meliputi data lintang, bujur, kedalaman gempa, dan magnitudo gempa. Data seismisitas yang digunakan berjumlah 100 data. Data lintang, bujur, kedalaman, dan magnitudo diperoleh dari United States Geological Survey (USGS, 2018). Peta dasar yang digunakan adalah peta geologi Lembar Tilamuta skala 1:250.000 (Bachri et al., 1993) dan peta Rupa Bumi Indonesia Lembar Bulontio skala 1:50.000 (Bakosurtanal, 1991).

Data gempabumi berupa lintang, bujur, dan kedalaman diolah menggunakan aplikasi Surfer dan aplikasi Sistem Informasi Geografis (SIG). Pengolahan data lintang, bujur, dan kedalaman gempa menghasilkan dua peta yaitu peta zonasi kedalaman gempa dan peta sebaran titik gempa berdasarkan kedalaman. Klasifikasi kedalaman gempa menggunakan klasifikasi Spence et al., (1989). Data gempabumi berupa lintang, bujur, dan magnitudo diolah menggunakan aplikasi Surfer dan aplikasi Sistem Informasi Geografis (SIG). Pengolahan data lintang, bujur, dan magnitudo gempa menghasilkan dua peta yaitu peta zonasi magnitudo dan peta sebaran titik gempa berdasarkan magnitudo. Klasifikasi magnitudo gempa menggunakan klasifikasi UPSeis (2014).

\subsection{Struktur Geologi}

Data struktur geologi diperoleh dari peta geologi Lembar Tilamuta (Bachri et al., 1993). Data kelurusan diperoleh dari data citra satelit Shuttle Radar Topography Mission (SRTM). Pergerakan struktur geologi aktif dapat memicu kegempaan di lokasi penelitian. Kaitan antara parameter gempa dengan struktur geologi di lokasi penelitian dianalisis berdasarkan keterdapatan gempabumi pada struktur geologi regional dan kelurusan. Kombinasi parameter gempa dengan struktur geologi dan kelurusan diolah menggunakan aplikasi Sistem Informasi Geografi (SIG) dan diagram roset.

\section{Hasil dan Pembahasan}

\subsection{Kegempaan Daerah Asparaga}

Peta pola sebaran titik gempa berdasarkan kedalaman menunjukkan bahwa terdapat gempabumi dangkal dengan kedalaman 0-70 km di daerah Asparaga. Titik gempa dangkal terdapat pada Diorit

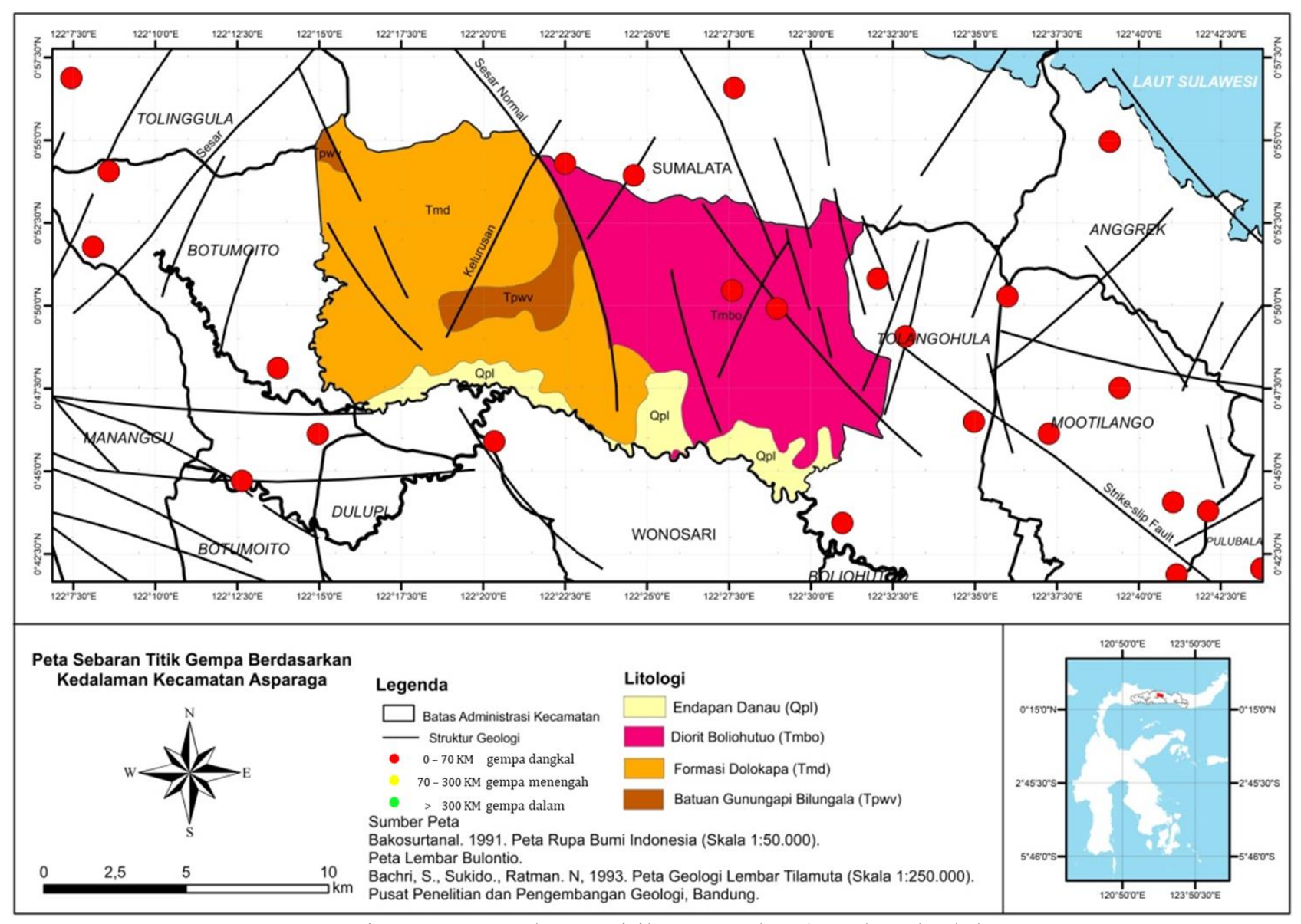

Gambar 2. Peta sebaran titik gempa berdasarkan kedalaman 


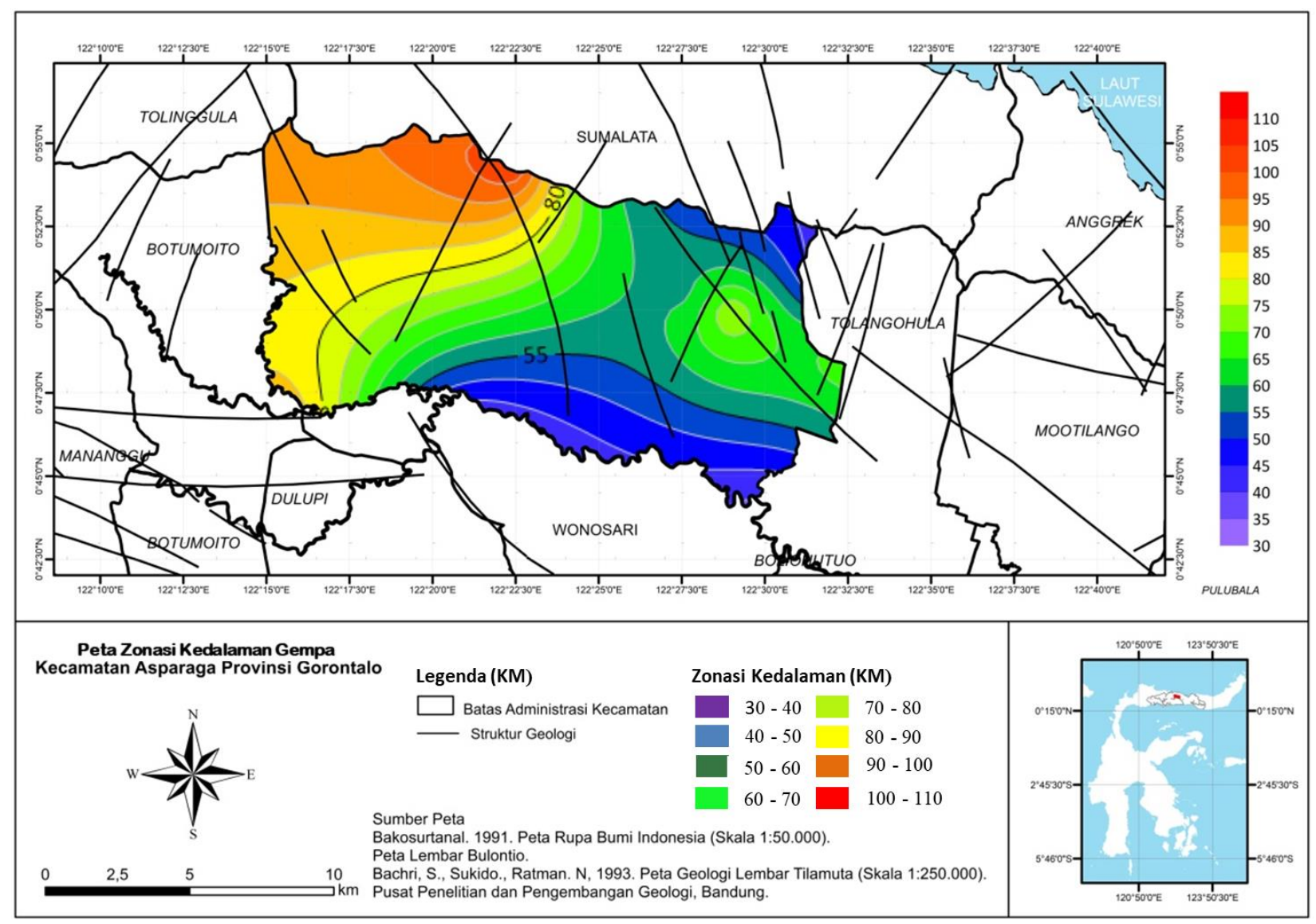

Gambar 3. Peta zonasi kedalaman gempa

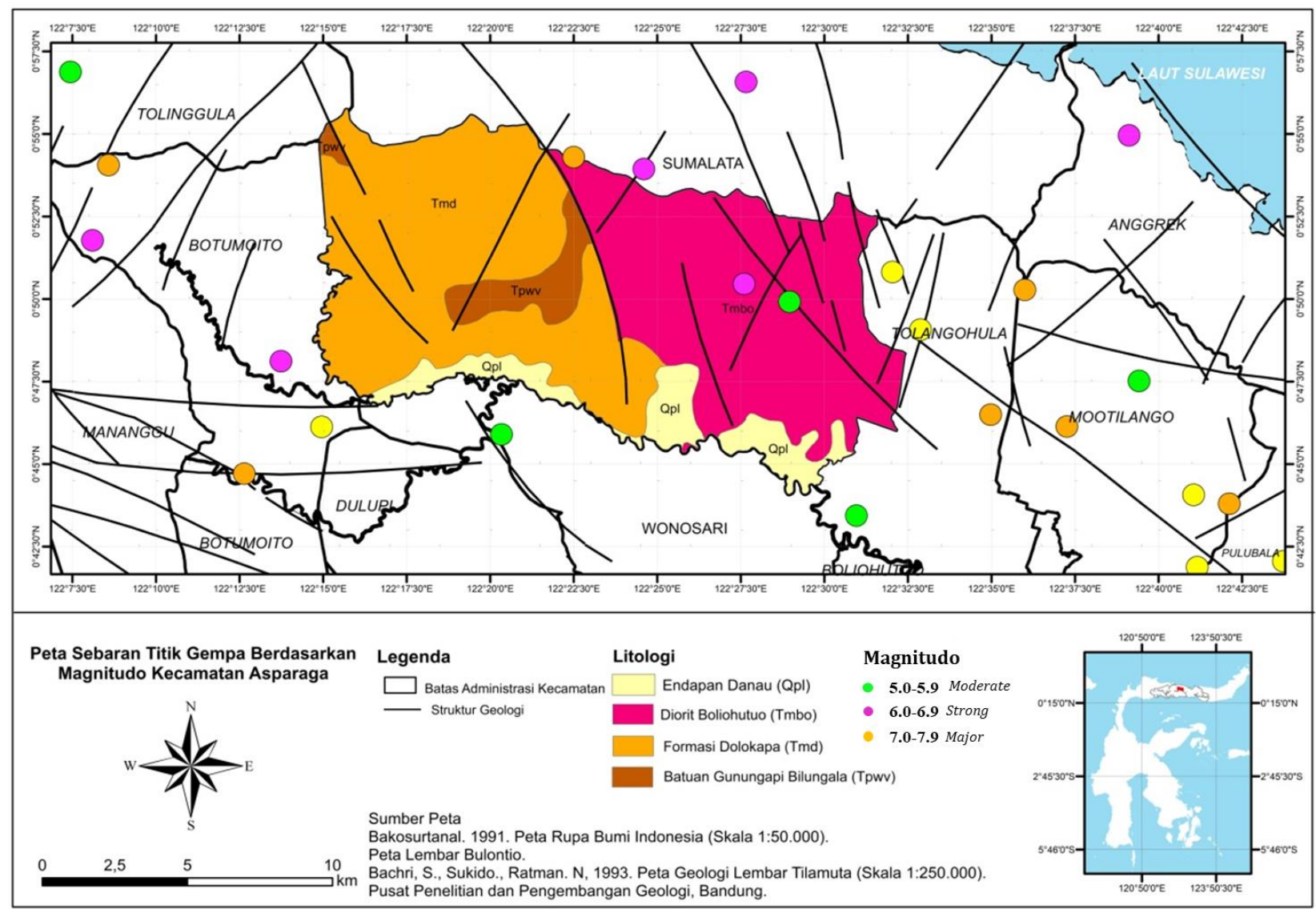

Gambar 4. Peta sebaran titik gempa berdasarkan magnitudo

Boliohuto yang tersusun atas batuan diorit dan granodiorit. Titik gempa dangkal berada di bagian timur daerah penelitian. Titik gempa tersebut terletak pada jalur struktur geologi sehingga dapat 


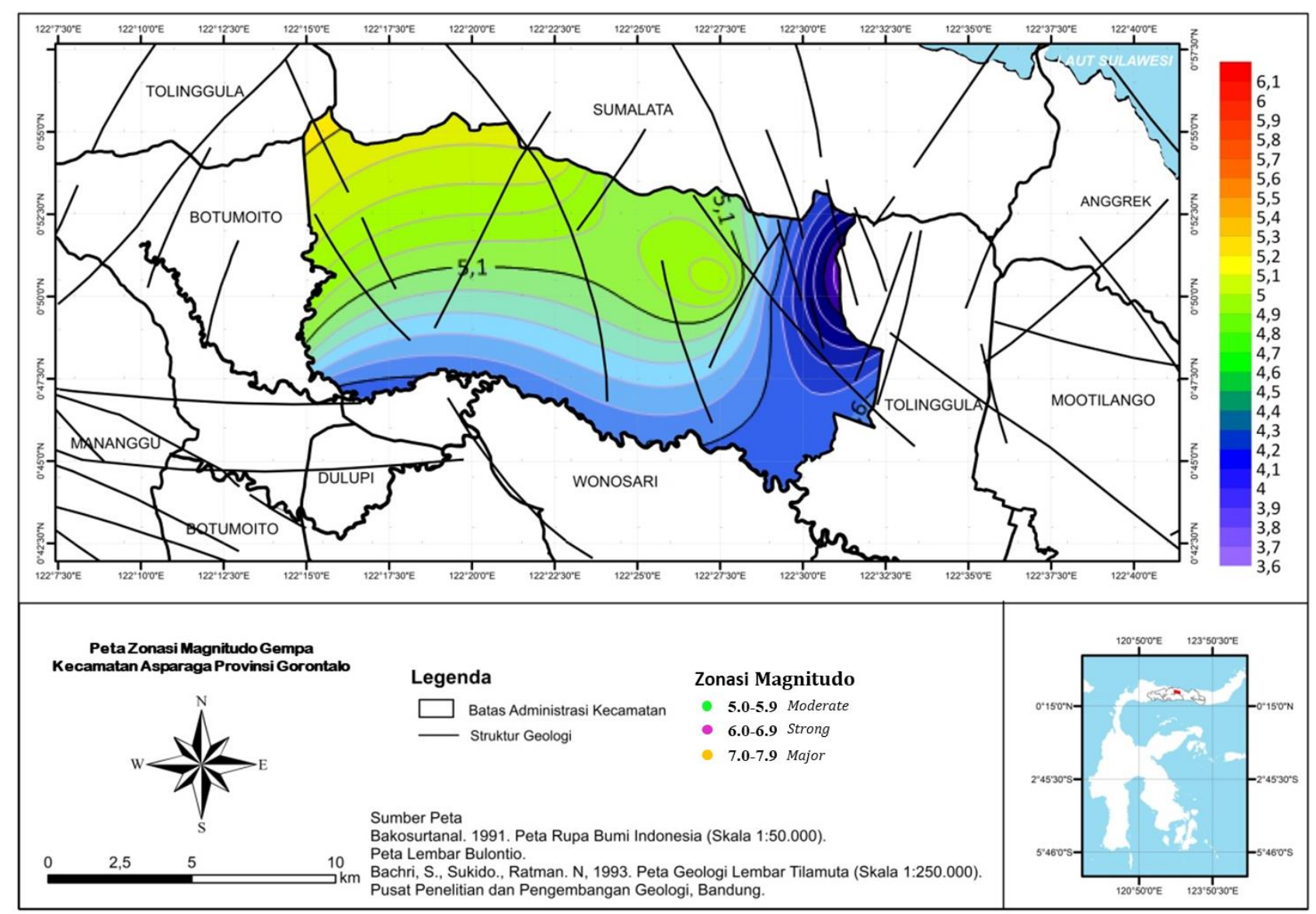

Gambar 5. Peta zonasi magnitudo gempa

diperkirakan bahwa struktur geologi tersebut menjadi penyebab utama adanya titik fokus gempa yang terjadi pada daerah Asparaga bagian timur.

Gempabumi dangkal di daerah Asparaga dapat berpotensi menyebabkan kerusakan terutama pada bagian timur daerah Asparaga. Hal ini dikarenakan oleh adanya titik-titik gempa dangkal pada bagian timur daerah Asparaga. Penyebab lainnya adalah karena terdapat gempabumi dangkal yang tepat berada di jalur struktur geologi (Gambar 2). Menurut (Pakpahan et al., 2015) gempabumi yang sangat berpotensi mengakibatkan kerusakan yaitu gempa yang bersumber dari sesar aktif. Hal ini dapat menimbulkan kerusakan lebih parah serta kerugian jika dibandingkan dengan gempabumi yang bersumber di dasar laut pada skala magnitudo yang sama.

Berdasarkan peta zonasi kedalaman gempabumi, zona kedalaman dangkal ditandai oleh warna ungu hingga hijau dan zona kedalaman menengah ditandai oleh warna kuning hingga merah. Daerah timur Asparaga berdasarkan zonasi kedalaman didominasi oleh gempa dangkal. Sedangkan daerah bagian barat dan sebagian besar bagian barat laut didominasi oleh gempa menengah (Gambar 3). Hal ini disebabkan oleh adanya titik-titik fokus gempa yang tersebar di daerah timur Asparaga dan sekitarnya.

Peta sebaran gempa berdasarkan magnitudo gempabumi di daerah Asparaga menunjukkan keterdapatan tiga titik gempa dengan magnitudo berbeda-beda yaitu magnitudo moderate (5.0-5.9 Mw) berwarna hijau, magnitudo strong (6.0-6.9 Mw) berwarna ungu, dan magnitudo major (7.0-7.9 Mw) berwarna jingga (Gambar 4). Ketiga titik gempa tersebut berada pada Formasi Diorit Boliohuto. Magnitudo moderate berada tepat di jalur struktur geologi. Magnitudo strong berada di bagian timur daerah penelitian, berdekatan dengan Magnitudo moderate namun tidak pada jalur struktur geologi. Magnitudo major berada di sebelah utara daerah penelitian.

Peta sebaran magnitudo gempa berdasarkan zonasi gempabumi menunjukkan bahwa sebagian kecil daerah Asparaga bagian timur dan selatan didominasi oleh magnitudo moderate. Semakin ke barat laut terjadi peningkatan magnitudo gempabumi (Gambar 5). Hal ini menunjukkan bahwa bagian timur daerah penelitian didominasi oleh gempa dangkal dan daerah barat didominasi gempa dengan magnitudo tinggi. Gempa dangkal memiliki bahaya yang lebih besar dibanding gempa dalam 


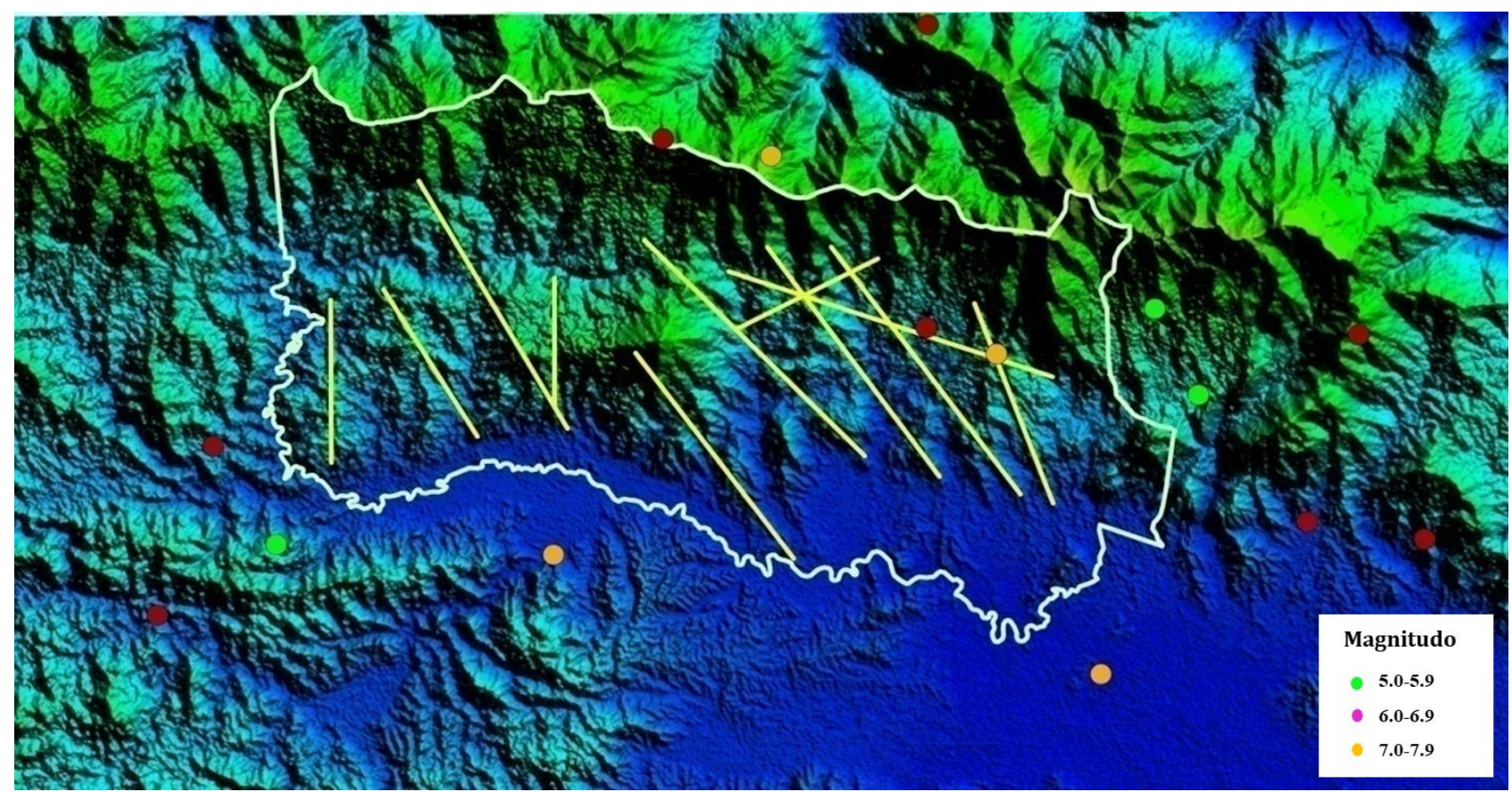

Gambar 6. Peta kelurusan berdasarkan data citra satelit SRTM

sedangkan magnitudo tinggi memiliki bahaya yang lebih besar dari magnitudo rendah. Sehingga daerah Asparaga baik di bagian barat maupun timur sama-sama memiliki bahaya yang besar.

\subsection{Kaitan Kegempaan dan Struktur Geologi}

Bagian timur daerah penelitian memiliki penyebaran titik episenter gempabumi yang relatif banyak. Kondisi ini diinterpretasikan karena adanya aktifitas struktur geologi. Titik gempa dangkal pada bagian timur daerah penelitian terletak pada jalur struktur geologi dengan Magnitudo 5.0-6.9 Mw. Adapun pada bagian barat daerah penelitian memiliki penyebaran titik gempa yang relatif sedikit dengan magnitudo 7.0 - 7.9 Mw. Peningkatan nilai magnitudo ke arah barat karena adanya perpotongan struktur geologi yang diduga sebagai sumber gempa magnitudo tinggi.

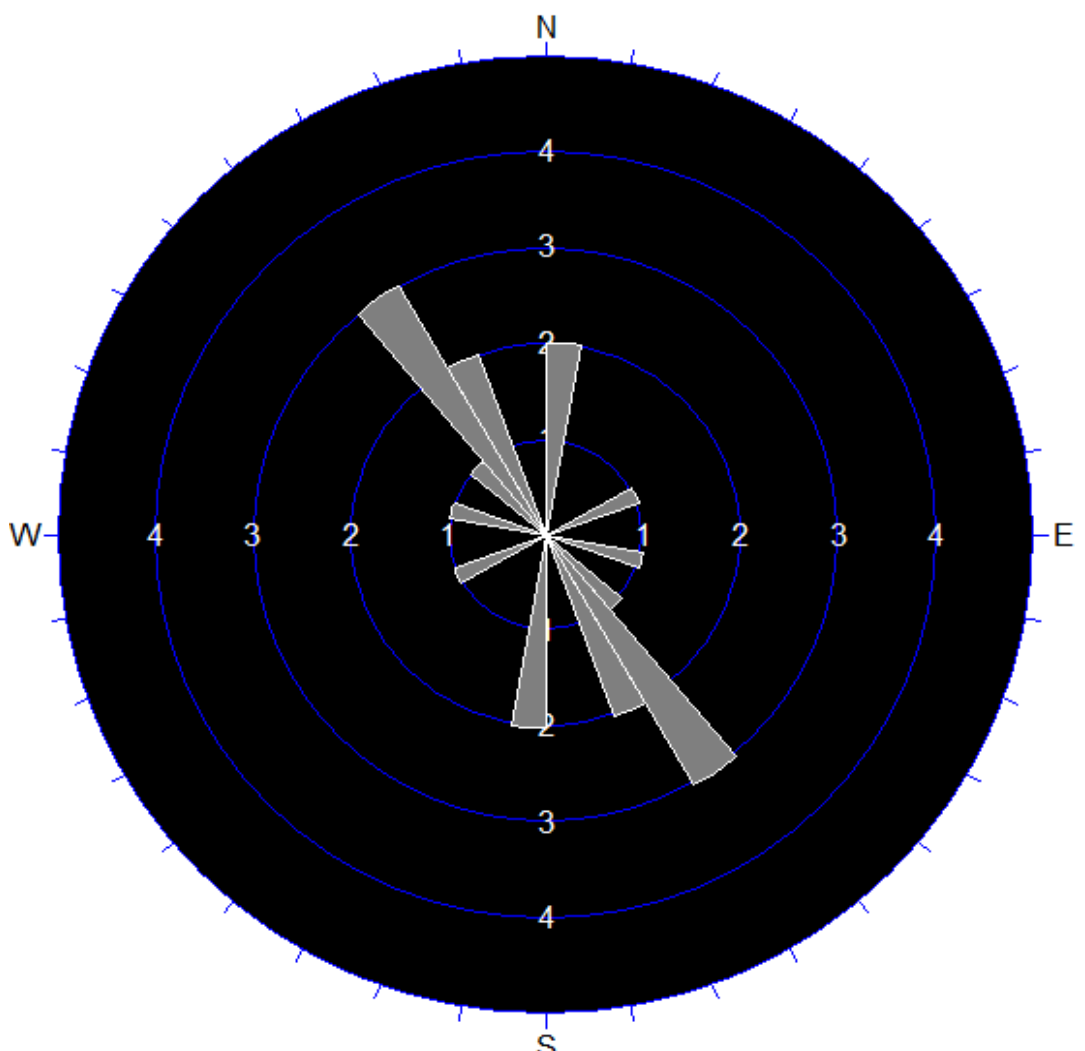

Apparent Strike

5 max planes / arc at outer circle

Trend / Plunge of

Face Normal $=0,90$ (directed away from viewer)

No Bias Correction

10 Planes Plotted

Within 45 and 90

Degrees of Viewing

Face

Gambar 7. Analisis arah tegasan menggunakan diagram roset 
Peta kelurusan menunjukkan bahwa terdapat titik gempa aktif yang berada tepat pada kelurusan (Gambar 6). Berdasarkan peta kelurusan dan hasil analisis kelurusan pada diagram roset diperoleh bahwa arah umum kelurusan yaitu barat laut-tenggara (Gambar 7).

\section{Kesimpulan}

Analisis gempabumi dan kaitannya dengan struktur geologi di daerah Asparaga telah dilakukan menggunakan data kedalaman gempabumi, magnitudo gempabumi, struktur geologi regional, dan SRTM. Hasil penelitian menunjukkan bahwa bagian timur daerah Asparaga didominasi oleh gempa dangkal dengan kedalaman $0-70 \mathrm{~km}$ dan daerah barat didominasi oleh gempa magnitudo tinggi 6.06.9 Mw. Bagian timur daerah penelitian didominasi oleh gempa dangkal karena adanya strukturstruktur geologi aktif yang tersebar di bagian timur daerah penelitian. Bagian barat didominasi oleh gempa magnitudo tinggi disebabkan oleh adanya perpotongan struktur geologi aktif. Analisis struktur geologi dan kelurusan menunjukkan bahwa titik gempa pada bagian timur daerah Asparaga tepat berada pada jalur struktur geologi dan kelurusan yang dominan berarah barat laut-tenggara. Struktur geologi di daerah penelitian berupa sesar aktif merupakan titik fokus gempa. Penelitian ini menunjukkan bahwa dominasi kegempaan berdasarkan kedalaman dan magnitudo serta keterkaitannya dengan struktur geologi dapat meningkatkan tingkat kerawanan gempabumi suatu daerah. Perlu dilakukan survei geologi untuk mengetahui litologi detail daerah Asparaga dan ground checking struktur geologi di lapangan serta perhitungan percepatan tanah maksimum daerah Asparaga. Perlu pula dilakukan sosialisasi dan upaya mitigasi di daerah Asparaga untuk meminimalisir akibat yang ditimbulkan oleh gempa.

\section{Ucapan Terima Kasih}

Penulis mengucapkan terima kasih kepada staf Laboratorium Teknik Geologi Universitas Negeri Gorontalo yang telah membantu dalam proses pengolahan data.

\section{Referensi}

Apandi, T dan Bachri, S. (1997). Peta geologi lembar Kotamobagu, Sulawesi. Bandung, Penelitian Dan Pengembangan Geologi.

Advokaat, E. L., Hall, R., White, L. T., Watkinson, I. M., Rudyawan, A., \& BouDagher-Fadel, M. K. (2017). Miocene to recent extension in NW Sulawesi, Ind onesia. Journal of Asian Earth Sciences, 147, 378-401.

Bachri, S., Sukido, \& Ratman, N. (1993). Peta Geologi Lembar Tilamuta, Sulawesi. Bandung, Pusat Penelitian dan Pengembangan Geologi.

Bakosurtanal (1991). Peta Rupa Bumi Indonesia. (Skala 1:50.000). Peta Lembar Bulontio.

Hall, R., \& Wilson, M. E. J. (2000). Neogene sutures in eastern Indonesia. Journal of Asian Earth Sciences, 18(6), 781-808.

Hinschberger, F., Malod, J. A., Réhault, J. P., Villeneuve, M., Royer, J. Y., \& Burhanuddin, S. (2005). Late Cenozoic geodynamic evolution of eastern Indonesia. Tectonophysics, 404(1-2), 91-118.

Manyoe, I. N., . L., Arif, S., \& Lahay, R. J. (2019). Earthquake Damage Level of Gorontalo Area Based on Seismicity and Peak Ground Acceleration. Jambura Geoscience Review, 1(1), 7. https://doi.org/10.34312/jgeosrev.v1i1.2018

Massinai, M. A., Harimei, B., Agustiawati, A., \& Massinai, M. F. I. (2019). Seismicity analysis Sulawesi North Arm based on B-Values. In Journal of Physics: Conference Series (Vol. 1341, No. 8, p. 082032). IOP Publishing.

Milsom, J. (2001). Subduction in eastern Indonesia: how many slabs. Tectonophysics, 338(2), 167-178.

Molnar, P., \& Dayem, K. E. (2010). Major intracontinental strike-slip faults and contrasts in lithospheric strength. Geosphere, 6(4), 444-467.

Pakpahan, S., Ngadmanto, D., \& Masturyono. (2015). Analisis Kegempaan di Zona Sesar Palu Koro, Sulawesi Tengah. Lingkungan Dan Bencana Geologi, 6(3), 253-264. https://scholar.google.co.id/scholar?hl=id\&as_sdt=0\%2C5\&q=analisis+kegempaan+zona+sesa $\mathrm{r}+$ palu+koro\&btnG $=$

Simandjuntak, T.O. (1992). Struktur Duplek (Dwi Unsur) Sesar Sungkup Sesar Jurus Mendatar di Lengan Timur Sulawesi. In Proceedings of the PIT XV IAGI. 
Soehaimi, A. (2008). Seismotektonik dan Potensi Kegempaan Wilayah Jawa. Indonesian Journal on Geoscience, 3(4), 227-240. https://doi.org/10.17014/ijog.vol3no4.20085

Spence, W., Sipkin, S. A., \& Choy, G. L. (1989). Measuring the size of an earthquake. Earthquakes \& Volcanoes, 21(1), 58-63.

UPSeis. (2014). Earthquakes Magnitude Scale and Classes. https://doi.org/10.1177/0733464814563606 Retrieved January 29, 2019, from http://www.geo.mtu.edu/UPSeis/magnitude.html

[USGS] United States Geological Survey. (2018). Magnitude / Intensity Comparison. Retrieved January 29, 2019, from Citing Internet sources URL https://earthquake.usgs.gov 